\title{
Exploring the eclectic world of Richard White (1800-1868), 2nd Earl of Bantry, Lord Berehaven: collector grand tourist nobleman
}

\section{Seana Vida Farrington}

Department of Art History in the Digital Arts \& Humanities Programme, UCC

The noblest motive is the public good (motto of the Earls of Bantry)

\section{'A Great Palace of Art on Bantry Bay'}

This is how Nigel Everett describes Bantry House in his Irish Arts Review article of 2010. Overlooking Bantry Bay in West Cork the house enjoys one of the most favourable aspects of any of Ireland's Big Houses (Figure 1). Everett's words are a most apt description for the project of ennoblement envisioned by Richard White (1800-1868), 2nd Earl of Bantry, Lord Berehaven, and for the collection of art he amassed.

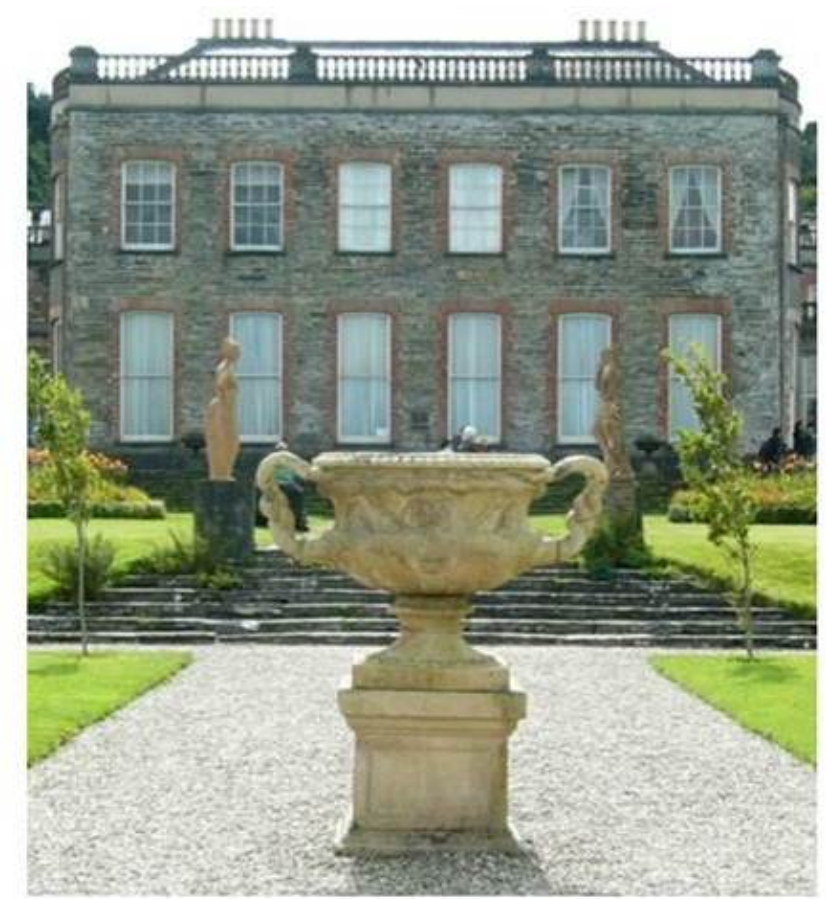

Figure 1: Bantry House, Bantry Bay, Cork. The central block is the oldest part of the house, to which the 1st and 2nd Earls added. Image: Seana Vida Farrington 


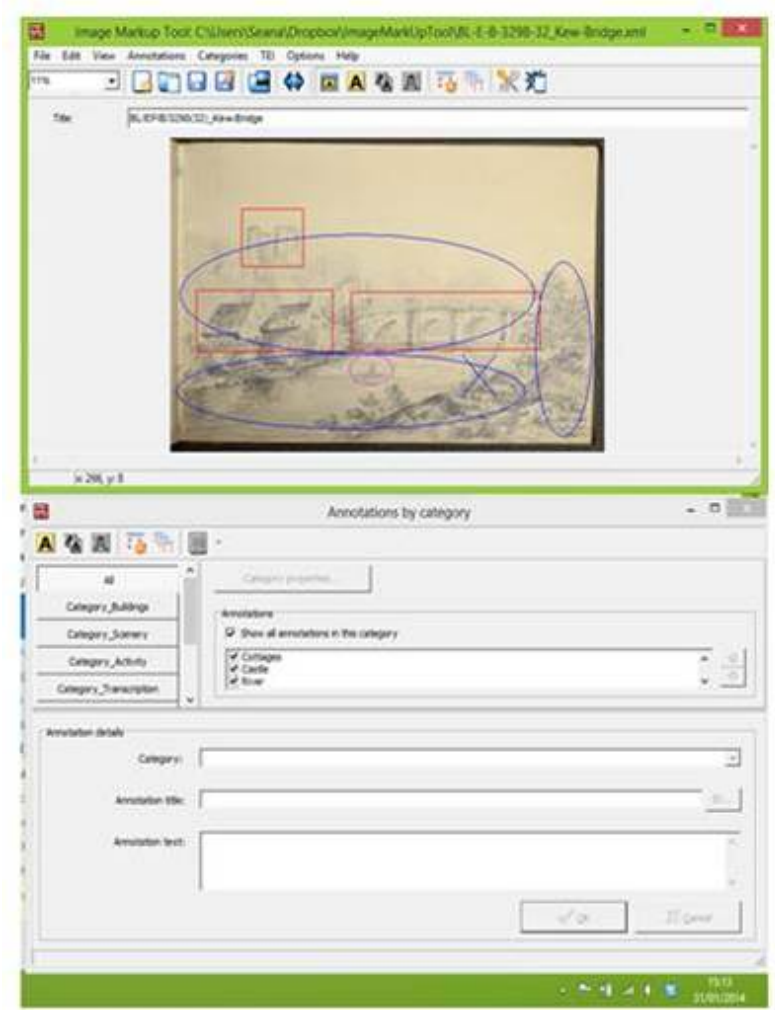

Figure 2: Screenshot showing the Image Markup Tool, used with permission from University of Victoria. UCC: BL/EP/B/3298: Kew Bridge, England.

As Berehaven travelled extensively he was often absent from Bantry. He visited the usual sites of the nineteenth century Grand Tour, also visiting Spain, Russia, the Baltics and Scandinavia. There were two activities he invariably participated in while travelling: sketching and collecting. The latter activity led to the creation of one of the most eclectic collections of art to grace an Irish home. Berehaven and his vision for Bantry House have not received sustained enquiry, which is a gap in knowledge I seek to address.

As is common in these types of houses much has been lost as subsequent generations dispersed both land and artefacts to meet their current financial needs. Added to those losses is the destruction of Berehaven's journals in a fire in the Estate Offices. Bantry and Berehaven are briefly mentioned by the novelist, poet and travel writer Lady Georgiana Chatterton (1806-1876) in Rambles in the South of Ireland during the year1838 by Lady Chatterton published in 1839, but otherwise there is a dearth of contemporary accounts regarding the Earl and his house.

With the loss of his journals, Berehaven's sketchbooks are the most important resource in reconstructing his journeys and in assessing how his experiences impacted on Bantry House. This research is being greatly aided by the use of digital tools and methodologies. Some are as basic as Google searches, or the creation of digital images of the sketchbooks. Other tools are more complex: for example, University of Victoria's Image Markup Tool that will be used to render those digital images searchable (Figure 2). 


\section{Fortune and Land}

The White family came from English merchant stock, with the Irish branch commencing in Limerick shortly after the Williamite wars (1689-1691). The first White recorded in Bantry is Captain Richard White who settled on Whiddy Island. In 1701, he had a son, also named Richard, later known as Counsellor White; it appears to be he who began to amass both fortune and land. It is easy to imagine this upwardly mobile family deciding upon a move to the Queen Anne style house across the bay, then called Blackrock. However, they remained on Whiddy until 1765 when Blackrock was vacated by its tenants, finally allowing the Whites to take possession of the property they had purchased fifteen years earlier.

Berehaven's father (another Richard White 1767-1851) began the family's elevation in 1797, with the creation of Baron. In 1796 he had had the opportunity to serve the Crown by raising the alarm when an armada of French ships appeared in Bantry Bay. He had also housed and provisioned the Crown's officers. His elevation continued, with the titles of Viscount in 1801 and Earl in 1816. By the time Berehaven was born in 1800 the Whites were the major landowners in the Bantry Bay and Beara peninsula areas of County Cork and reasonably well-established; but their elevation was new. Arguably, this is from where Berehaven's desire to assert the family dignity and ennoble Bantry House grew.

\section{Country Pursuits or Art}

That the 1st Earl's reward may not have been much to his taste has been speculated upon elsewhere. However, he was obliged to live-up to his new position. That some enlargement of the property was planned is evident in an inscription 'Coade Stone London 1796'. Those plans may have been further expanded upon due to the recent demands upon the Earl's hospitality; John Cornforth has argued that the 1st Earl's contribution to Bantry House does not receive adequate recognition. With little taste for ostentatious display the 1st Earl's interests and tastes in life were certainly different from those of his son. He was known for enjoying country pursuits, dwelling happily among his tenants and speaking Irish; whereas Berehaven had no taste for the saddle, preferring art.

It is thought that Berehaven kept away from home due to these differences, which seems to be supported by the earliest of his sketchbooks. Dating from 1813 and 1817, they create a picture of a youth who loved to roam. They might also prove of interest to antiquaries as they contain pictures of ruins and castles no longer extant. Like many young men and women of his day he took drawing lessons under a master and in a practice that was life-long an improvement in his efforts may be noted. A sketchbook in the UCC archive (BL/E/B/3298) places him at Kew, on the Cornish coast and in Glanmire at the tender age of thirteen. So, it appears his wanderlust began early. 


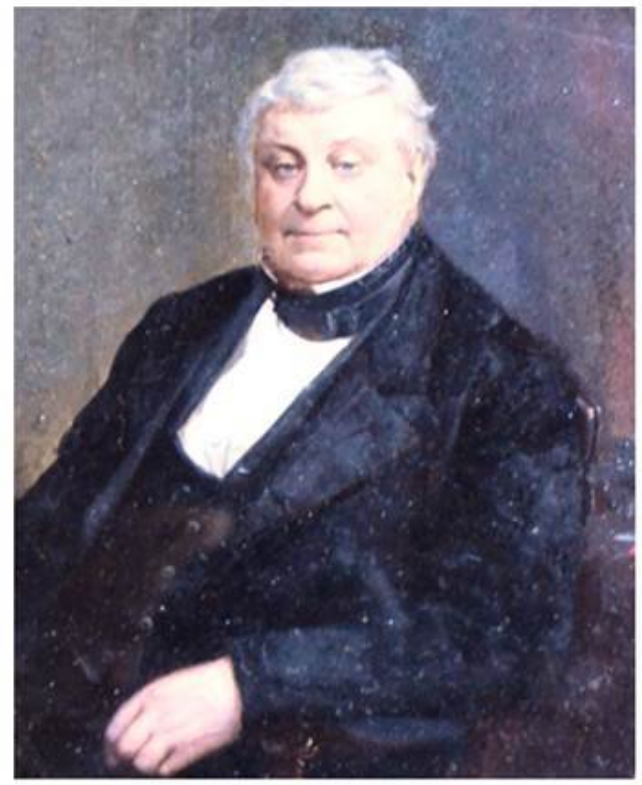

Figure 3: Richard White, 2nd Earl of Bantry, Lord Berehaven. Image: Seana Vida Farrington.

\section{Lord Berehaven and the Grand Tour}

How delightful it would be for Ireland if many more of its young Peers followed Lord Berehaven's example... (Lady Chatterton, 1839)

The 1st Earl was not only a nobleman he was also very wealthy, enjoying an income of $£ 9,000$ per annum. He also married well; his wife's dowry was $£ 30,000$. In keeping with his father's position Berehaven was sent away to be educated, and while it seems Berehaven was not a favourite, presumably his first tour of Europe would have been funded by his father.

This period of travel, known as The Grand Tour, was considered to be an essential part of a nobleman's education and a rite of passage. It was an opportunity for young nobles to experience, at first hand, the art and culture of Europe and to develop the manners and contacts that would be important to them in their role as leaders in politics, diplomacy and society.

Berehaven's passports record his journeys from 1826, which agrees with sketchbooks in the Bantry Papers archive. What Berehaven was doing and where he was prior to this has yet to come to light. His early sketches suggest he spent his time between his home and various places in England. If his relationship with his father was strained, increasing tension might have prompted the young lord to begin his travels. 


\section{Treasures from near and afar}

The walls, staircase and bedrooms are all covered in tapestry - even ceilings of the staircases and passages... some of it very good, especially that in the drawing room, which once adorned the palace of the Tuileries (Lady Chatterton, 1839)

For over 35 years Berehaven travelled (Figure 3). He visited Europe, Euro-Asia and the Baltics. He bought art, plants and decorative items that were shipped home to be opened immediately, or upon his return. Items remaining in Bantry House include a set of Aubusson Royale tapestries made for Marie Antoinette, 18th century Savonnerie carpets, a 19th century Dutch chandelier decorated with Meissen porcelain flowers, a shrine of icons from Russia and fragments of the gilt tooled Spanish leather that adorned not only the fine doors, but every crack and crevice he could think of.

Berehaven also supported Irish craftsmen. Among the mystery items of the house are some important fireplaces. Two are of Irish manufacture and two of Italian, but with scant documentary evidence it is not possible to state with certainty which fireplaces were produced locally and which were sent from Italy. A fifth fireplace designed by Angelica Kauffman (1741-1807) is as likely to date from the 1st Earl's interventions, as from Berehaven's. There are other Irish items that due to their dates of manufacture could have been purchased by either father or son, as it is clear that Berehaven's taste was not limited to the contemporary.

In 1836 Berehaven married Lady Mary O'Brien, a daughter of the Marquis of Thomond. An established traveller by this time, Berehaven continued his nomadic lifestyle accompanied by Mary. 1843 found the couple in Rome where they sat to John Hogan, an Irish sculptor. Two fine marble busts were the result, which still grace Bantry House. With them in the entrance hall are beautiful painted tiles from Giustiniani of Naples (Figure 4), along with a number of pieces in their style; one elegant Egyptian head bears their mark (Figure 5).

This is just a fraction of what remains in Bantry House, and that is perhaps only $20 \%$ of what the 2nd Earl collected. Brigitte Shelswell- White, the estate's current owner and custodian, suggests $20 \%$ is a generous estimate. Among the most famous of the losses is a series of paintings by Francesco Guardi (1712-1793) that Berehaven purchased in Italy when only 20 years of age. This purchase places Berehaven on the Continent at least six years before the date suggested by his passports.

Information about Berehaven remains elusive. Piecing together his whereabouts through the use of his sketchbooks and purchases can be greatly aided by the use of digital tools. Digital maps and timelines, unlike their print counterparts, allow new information to be updated as it becomes available and are especially useful if hosted online in collaborative spaces. 


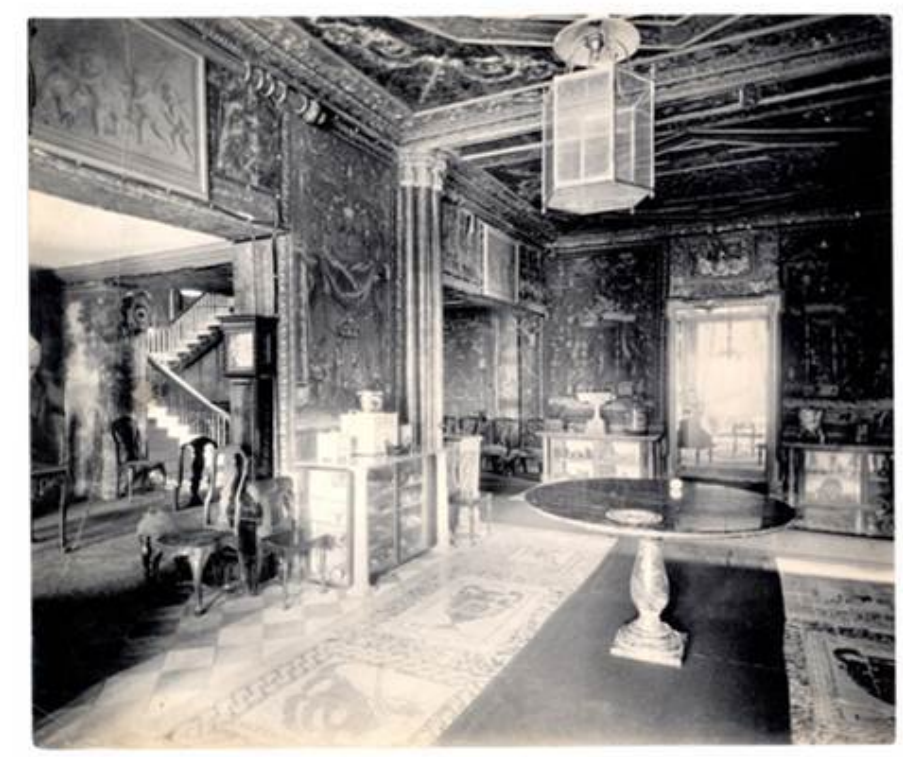

Figure 4: UCC: BL/EP/B/3557 Bantry House entrance hall as it appeared in the late 19th century. Note the painted floor tiles from Giustiniani, Naples. CUCC Library, University College Cork

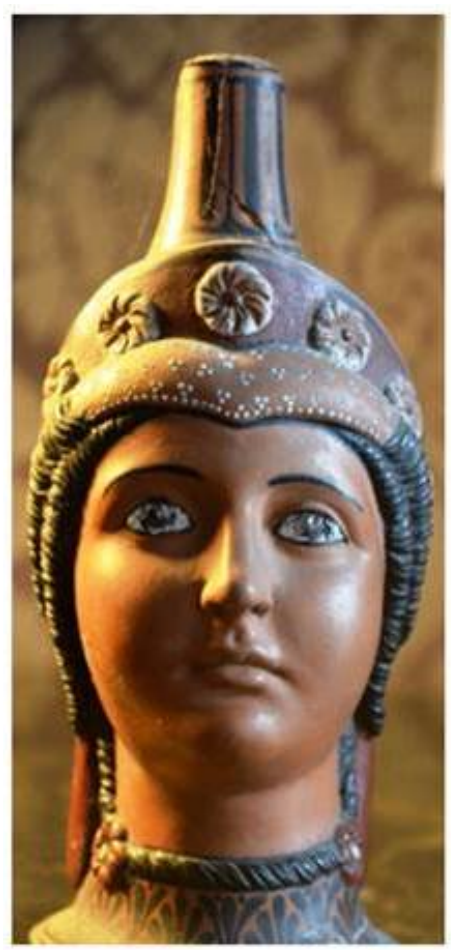

Figure 5: Giustiniani: Elegant Egyptian head Cork: Bantry House. Image: Seana Vida Farrington. 


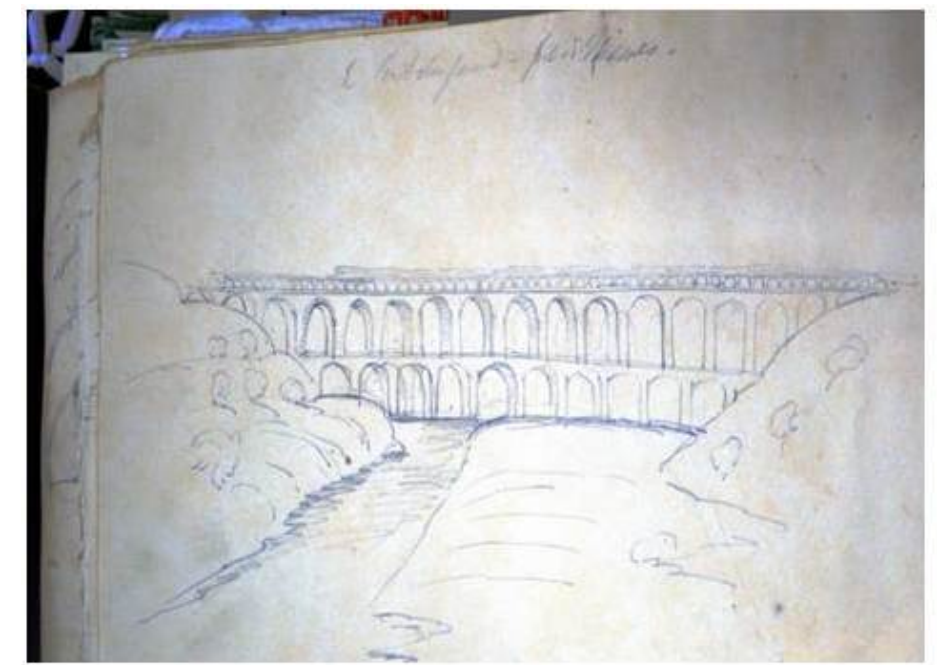

Figure 6: UCC: BL/EP/B/3306: Le Pont du Gard, pres Nismes CUCC Library, University College Cork. Image: Seana Vida Farrington

\section{Digital Humanities}

The keeping of diaries enjoys a long tradition and we are indebted to those men and women who chose to write about their daily lives, but there are particular frustrations when working with personal memoranda. For example, diaries often contain nicknames and abbreviations that the diarist had no need to 'spell out' because he or she knew exactly to whom, or what, they referred.

Likewise, Berehaven was not concerned with posterity. Many of his sketches show unidentified places, people and objects. Even when inscribed, his annotations can be confusing. For example, his unfinished drawing 'Le Pont du Gard, pres Nismes' references an ancient place name (Figure 6). We do not know why he left his sketch unfinished, or why he chose to use an appellation that would lead the detecting historian to Nismes in Belgium, rather than Nîmes in France. Online tools are useful with the latter problem. Typing confusing inscriptions into Google is often fruitful; even when photographic results are not an exact match, they can help to confirm a place name (Figure7).

One thing 'the digital' allows is immediacy of communication, but more importantly it has increased the options of how we can visualise and present the results of our research; the most liberating aspect of this is that our projects can remain open. Discussion can be invited, and help sought, through online fora. The 'digital turn' echoes Berehaven's own mix-and-match approach to furnishing and decorating his home. By employing technologies and methods both old and new to draw out the stories hidden within Berehaven's sketchbooks we come to more fully appreciate his buying and collecting strategies.

We will never know Bantry House in all its glory, under the spell of West Cork light coming in off the Bay, or the flickering candlelight of his beautiful Baltic chandeliers and sconces. 


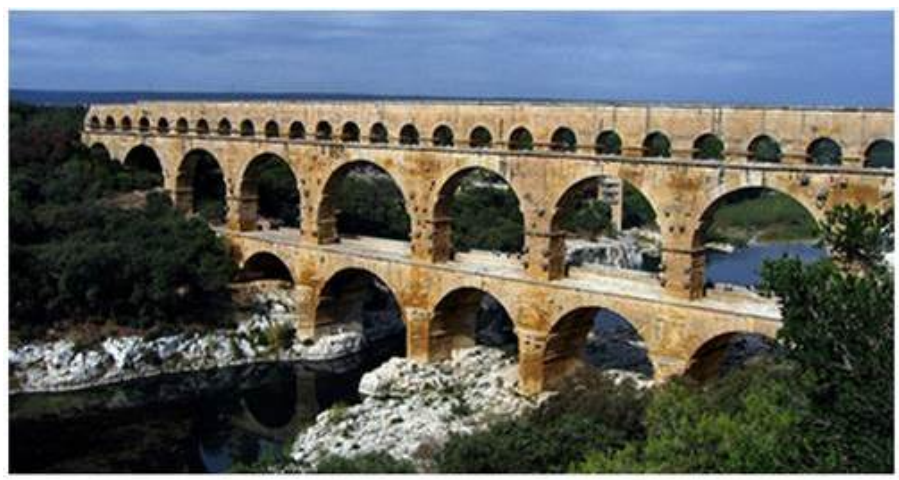

Figure 7: Emanuele: Pont du Gard, Roman Empire. Digital photograph. October 2007 Wikipedia.org: Licensed under the Creative Commons Attribution-Share-Alike 2.0 Generic Licence

But, it might be possible to gather enough information to virtually interpret his vision, so that we too may experience something of Lady Chatterton's wonderment.

With thanks to my supervisors, Dr Flavio Boggi (Art History) and Dr Orla Murphy (Digital Arts and Humanities) and to my colleagues in the Digital Arts and Humanities programme. I also wish to gratefully acknowledge the Digital Arts and Humanities Board, UCC; the College of Arts Celtic Studies and Social Sciences; and the Boole Library through whom this research is funded. 